medRxiv preprint doi: https://doi.org/10.1101/2020.12.18.20248340; this version posted December 20, 2020. The copyright holder for this preprint (which was not certified by peer review) is the

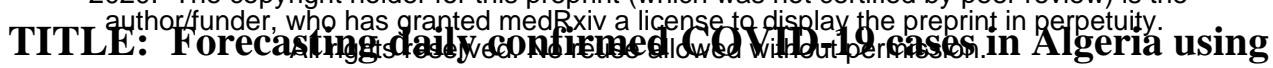

\title{
ARIMA models
}

Messis Abdelaziz ${ }^{1,2}$; Adjebli Ahmed ${ }^{3}$; Ayeche Riad $^{4}$;Ghidouche Abderrezak ${ }^{2}$; Ait-Ali Djida ${ }^{2}$

${ }^{1}$ Université de Bordj Bou Arréridj; El-Anasser, 34010, Bordj Bou Arréridj, Algérie;

${ }^{2}$ Laboratoire de Génie Biologique des Cancers, Université de Bejaia 06000, Bejaia, Algérie;

${ }^{3}$ Laboratoire d'Ecologie Microbienne, faculté des sciences de la nature et de la vie, université de Bejaia, 06000, Bejaia, Algérie;

${ }^{4}$ Laboratoire Caractérisation et Valorisation des Ressources Naturelles, Université de Bordj Bou Arreridj, 34010, El-Anasser, Bordj Bou Arréridj, Algérie Corresponding Author: a.azizmessis@gmail.com 
medRxiv preprint doi: https://doi.org/10.1101/2020.12.18.20248340; this version posted December 20, 2020. The copyright holder for this preprint (which was not certified by peer review) is the ABSTRACTh/funder, who has granted medRxiv a license to display the preprint in perpetuity.

Coronavirus disease has become a worldwide threat affecting almost every country in the world. The aim of this study is to identify the COVID-19 cases (positive, recovery and death) in Algeria using the Double Exponential Smoothing Method and an Autoregressive Integrated Moving Average (ARIMA) model for forecasting the COVID-19 cases.

The data for this study were obtained from March $21^{\text {st }}, 2020$ to November $26^{\text {th }}$, 2020. The daily Algerian COVID-19 confirmed cases were sourced from The Ministry of Health, Population and Hospital Reform of Algeria. Based on the results of PACF, ACF, and estimated parameters of the ARIMA model in the COVID-19 case in Algeria following the ARIMA model $(0,1,1)$. Observed cases during the forecast period were accurately predicted and were placed within the prediction intervals generated by the fitted model. This study shows that ARIMA models with optimally selected covariates are useful tools for monitoring and predicting trends of COVID-19 cases in Algeria.

Keywords: COVID-19, Time series, Double Exponential Smoothing, ARIMA; forecast, Algeria. 
medRxiv preprint doi: https://doi.org/10.1101/2020.12.18.20248340; this version posted December 20, 2020. The copyright holder for this preprint (which was not certified by peer review) is the

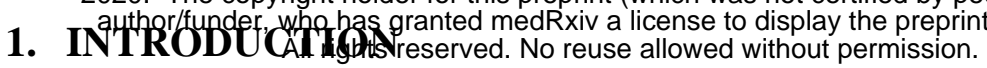

On March $11^{\text {th }}, 2020$, the World Health Organization (WHO) declared COVID-19 as a worldwide pandemic. In December, 2019, a local outbreak of pneumonia of initially unknown cause was detected in Wuhan (Hubei, China), and was quickly determined to be caused by a novel coronavirus [1], namely severe acute respiratory syndrome coronavirus-2 (SARS-CoV-2) [2]. The outbreak has since spread to every province of mainland China firstly and has been propagated around countries and regions of the world. The contagious COVID-19 devastated normal life around the world. As of November $26^{\text {th }}, 2020$, COVID-19 has infected more than 60776978 confirmed cases in the world, has killed more than 1428228 people, and has forced more than 7 billion to stay in their homes [3]. In response to this ongoing public health emergency, an online interactive dashboard has been developed, hosted by the Center for Systems Science and Engineering (CSSE) at Johns Hopkins University, Baltimore, MD, USA, to visualize and track in real time reported cases of coronavirus disease 2019 (COVID-19) in the world [3].

Coronaviruses are a large family of viruses with some causing less-severe disease, such as the common cold, and others more severe disease such as MERS and SARS. Some transmit easily from person to person, while others do not. 
some patients and does not transmit readily between people.

The new coronaviruses lurking around the world are threatening our rules, and the prevalence of fear and panic is increasing. It has also affected the cryptocurrency market [4-5].

Algeria reported its first COVID-19 case, on February $25^{\text {th }}, 2020$. In November $26^{\text {th }}, 2020$, Algeria has reported 79110 confirmed cases with 51334 recoveries and 2352 deaths by COVID-19 [6].

Countries all over the world are challenged with this virus and have declared lockdowns in their various cities and states. The researchers estimate that the virus proliferates to more than two persons from every infected person, highlighting the possibility to infect millions [6]. In order to control this pandemic, Algerian government has instituted on March $23^{\text {rd }}, 2020$, several nonpharmaceutical intervention strategies. Thus strategies along with other measures such as social distancing, isolation and quarantine aimed to break the chain of transmission of COVID-19 in Algeria [7]. These measures were implemented with the aim to flatten the pandemic curve and prevent an exponential rise in new COVID-19 infections that would allow for the effective management and control of the pandemic. 


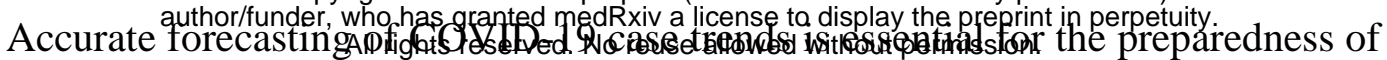

health systems in terms of outbreak management and resource planning.

Mathematical and statistical modeling of infectious disease is effective tools that would enable health systems to anticipate future disease trends [8-9]. Time series models such as the Autoregressive Integrated Moving Average (ARIMA) have been widely used to statistically model and forecast infectious disease trends [10]. ARIMA models are preferred in this context as they are suitable for investigations into short-term effects of acute infectious diseases and are a flexible class of models that are appropriate to fit several trajectories, and have been well documented in the literature [10-11]. ARIMA models have been used in several studies to forecast the COVID-19 outbreak trends [12-13-14-15]. However, to date, there are no studies conducted using ARIMA models to forecast the COVID-19 cases outbreak in Algeria. In this study, ARIMA models were developed using daily COVID-19 confirmed and active cases in Algeria to identify the best fitting model COVID-19 cases from March 21 $1^{\text {st }}, 2020$ to November $26^{\text {th }}, 2020$. Forecasting future COVID-19 cases using ARIMA models are suitable especially when model parameters that determine the disease dynamics are unavailable or undetermined due to the disease novelty. In addition, ARIMA models are a flexible, empirical method which is able to produce reliable 
models are able to provide reasonable forecasts even with the above mentioned limitations.

\section{MATERIALS METHODS}

\section{Data source}

Data for this study were obtained from March $21^{\text {st }}, 2020$ to November $26^{\text {th }}, 2020$.

The daily Algerian COVID-19 confirmed cases were sourced from The Ministry

of Health, Population and Hospital Reform. Daily COVID-19 confirmed cases for neighboring countries were also obtained from the Johns Hopkins University's official website [6].

\section{Methods}

The Exponential Smoothing method and Autoregressive Integrated Moving Average (ARIMA) processes refer to [16] with the following equation:

- Determine the first smoothing value and determine the parameter $\alpha$

$S t^{\prime}=\alpha X+(1-\alpha) S t-1^{\prime}$

- Determine the second smoothing value $S t^{\prime \prime}=\alpha S t^{\prime}+(1-\alpha) S t-1 "$

- ARIMA Model For Time Series Data ARIMA model is stated as follows: 
medRxiv preprint doi: https://doi.org/10.1101/2020.12.18.20248340; this version posted December 20,

2020. The copyright holder for this preprint (which was not certified by peer review) is the

$\phi(B)(1-B) d X t=Q^{\prime}(1 B$ ightigts reserved. No reuse allowed without permission.

ARIMA forecasts on its previous past values and portrayed by 3 terms- p, d, q.

Where, $\mathbf{p}$ is the order for the Auto Regressive expression (AR), $\mathbf{q}$ is the order for the Moving Average expression (MA) and $\mathbf{d}$ is the Number of differencing required making the time arrangement fixed.

Our goal is to that optimizes the metric of interest [17]. The experiment is carried out in Minitab 17 Programming software. In general equation can be approached using a regression model:

$y t=\alpha+\beta 1 y t-1+\cdots+\beta p y t-p+\beta 1$ et $-1+\cdots+\beta q e t-q+\varepsilon t$

\section{RESULTS}

Using the time-series model approach, the pattern of COVID-19 data distribution behavior in Algeria shows an exponential distribution pattern, where the addition of positive cases of COVID-19 increases significantly every day of the epidemic.

This condition is also followed by a distribution pattern of the number of people who recovered and died (Figure 1). As we know that in the time-series model the type of exponential distribution consists of a single exponential, double 
is the double exponential model [18].

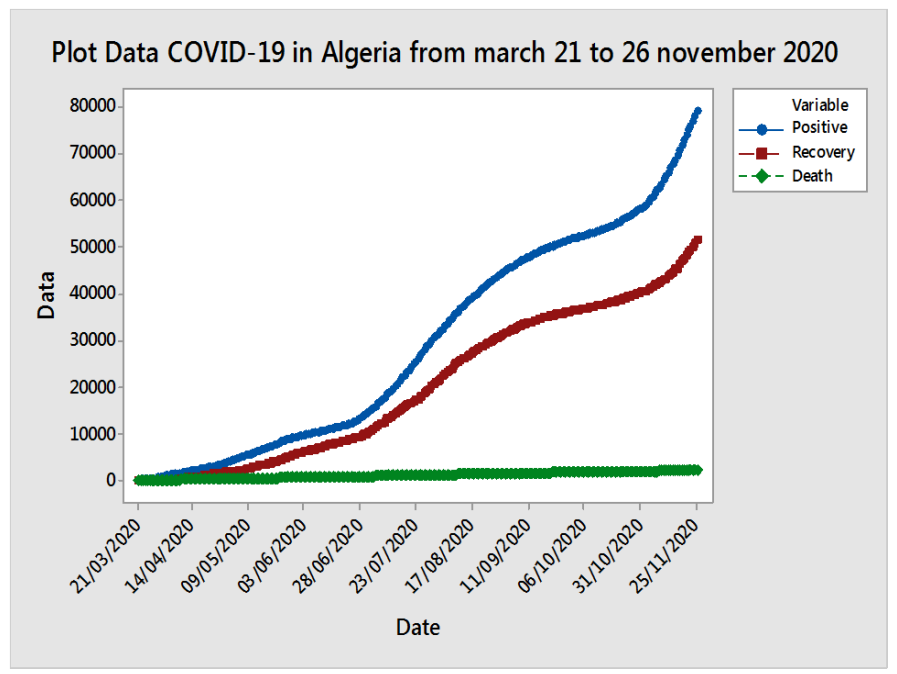

Figure 1. Plot Data COVID-19 in Algeria (Data processed by Minitab 17)

By using a 10 percent error rate, the best $\alpha$ parameter values are 0.745 and the best $\gamma$ is 1.421 with a Mean Absolute Percentage Error (MAPE) of 0.49 percent.

MAPE is the error value for each period divided by the actual observation value for that period (Figure 2). In positive COVID-19 cases, the MAPE value is smaller than the error rate at $10 \%$.

The increase in the number of people who were positive for COVID-19, also directly affected the model of prediction patients who recovery and death (Figure 3 and Figure 4). 
medRxiv preprint doi: https://doi.org/10.1101/2020.12.18.20248340; this version posted December 20, 2020. The copyright holder for this preprint (which was not certified by peer review) is the author/funder, who has granted medRxiv a license to display the preprint in perpetuity.

All rights reserved. No reuse allowed without permission.

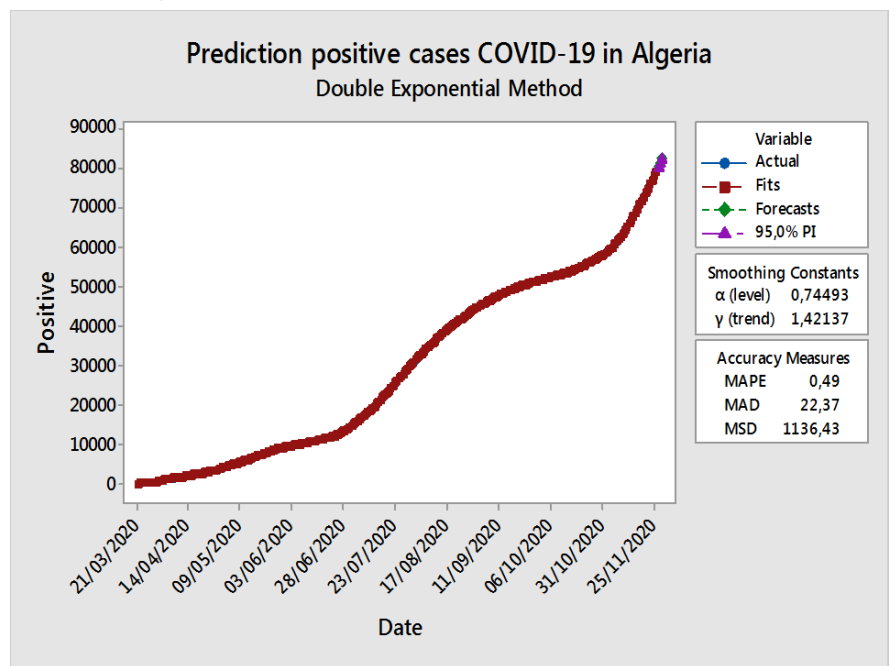

Figure 2. Prediction positive COVID-19 cases in Algeria (Data processed by Minitab 17)

Based on Figure 3, using a 10 percent error rate, the estimated value of the parameter recovery patients at $\alpha$ is $0.464, \gamma$ is 0.662 and the MAPE of 1.89 percent. In the recovery of COVID-19 cases, the MAPE value is smaller than the error value set at 10 percent error rate. The cure rate of COVID-19 patients is increasing simultaneously with the number of positive cases because of the health measures taken by the government since march $21^{\text {st }}, 2020$, and probably also due to the age of Algerian community which is relatively young. 
medRxiv preprint doi: https://doi.org/10.1101/2020.12.18.20248340; this version posted December 20, 2020. The copyright holder for this preprint (which was not certified by peer review) is the author/funder, who has granted medRxiv a license to display the preprint in perpetuity.

All rights reserved. No reuse allowed without permission.

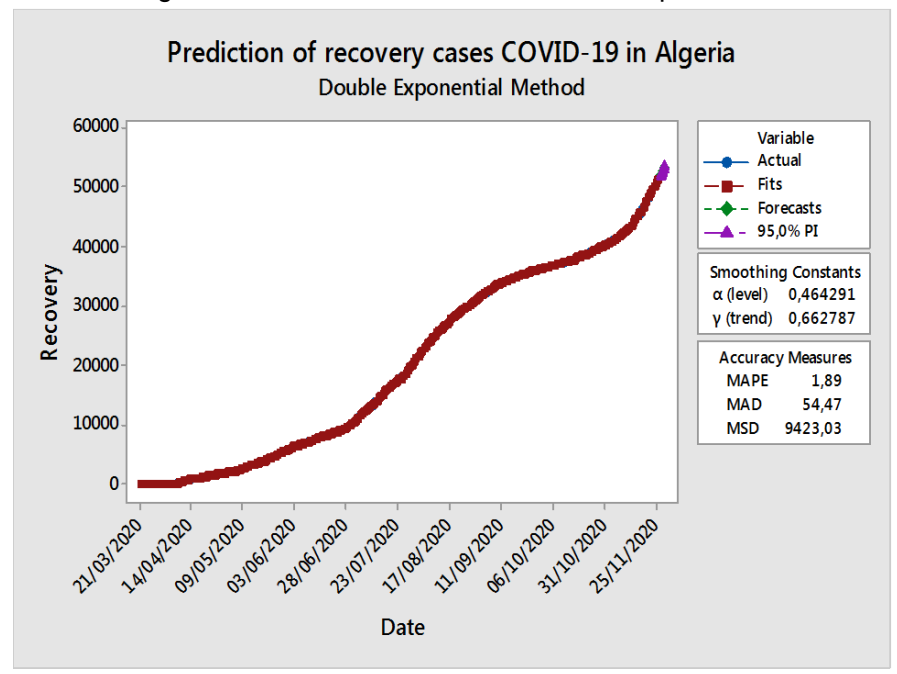

Figure 3. Prediction Recovery COVID-19 cases in Algeria (Data processed by Minitab 17)

Using a 10 percent error rate, the estimated value of the parameter death patients at $\alpha$ is $0.904, \gamma$ is 0.472 , and the MAPE of 0.765 percent. Death cases of COVID19, the MAPE value is greater than the error value set at 10\% (Figure 4). The increase in mortality is possibly due to the degree of infection and also the medical history of patients COVID-19. 
medRxiv preprint doi: https://doi.org/10.1101/2020.12.18.20248340; this version posted December 20, 2020. The copyright holder for this preprint (which was not certified by peer review) is the author/funder, who has granted medRxiv a license to display the preprint in perpetuity.

All rights reserved. No reuse allowed without permission.

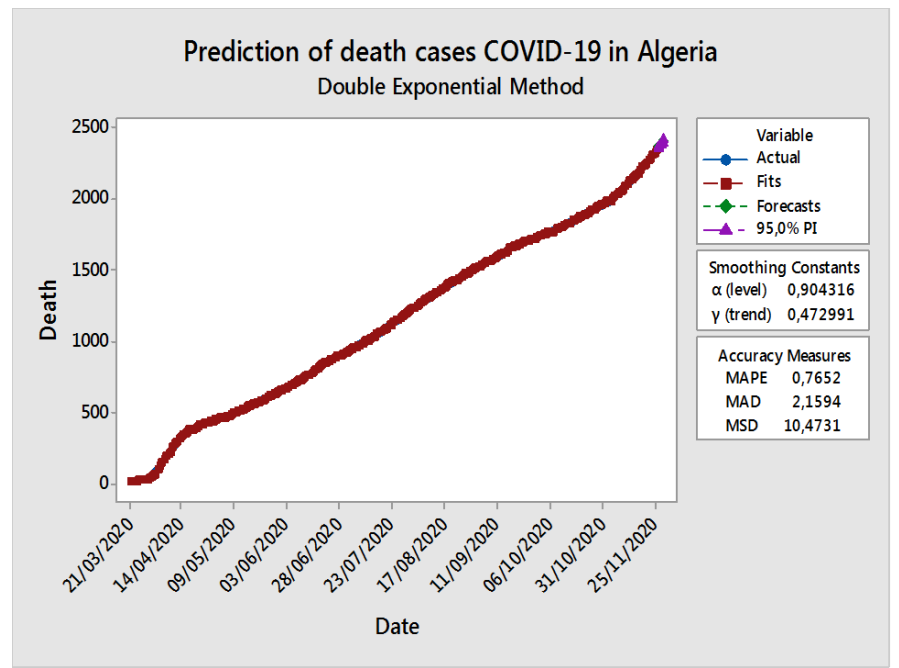

Figure 4. Prediction Death COVID-19 cases in Algeria (Data processed by Minitab 17)

After the parameter values, $\alpha$ and $\gamma$ are obtained, the next step is the identification process Partial Autocorrelation Function (PACF) and Autocorrelation Function (ACF) from positive, recovery, and death data. PACF and ACF tests are used to test the accuracy of the results of the double exponential smoothing model and a means of determining the stationarity of the variable and the lag lengths of the ARIMA model.

Based on Figure 5, PACF and ACF plots of Residuals for COVID-19 positive data are obtained. The lag times through PACF cuts off at lag one, and ACF tails off slowly. 
medRxiv preprint doi: https://doi.org/10.1101/2020.12.18.20248340; this version posted December 20,

2020. The copyright holder for this preprint (which was not certified by peer review) is the author/funder, who has granted medRxiv a license to display the preprint in perpetuity.

All rights reserved. No reuse allowed without permission.
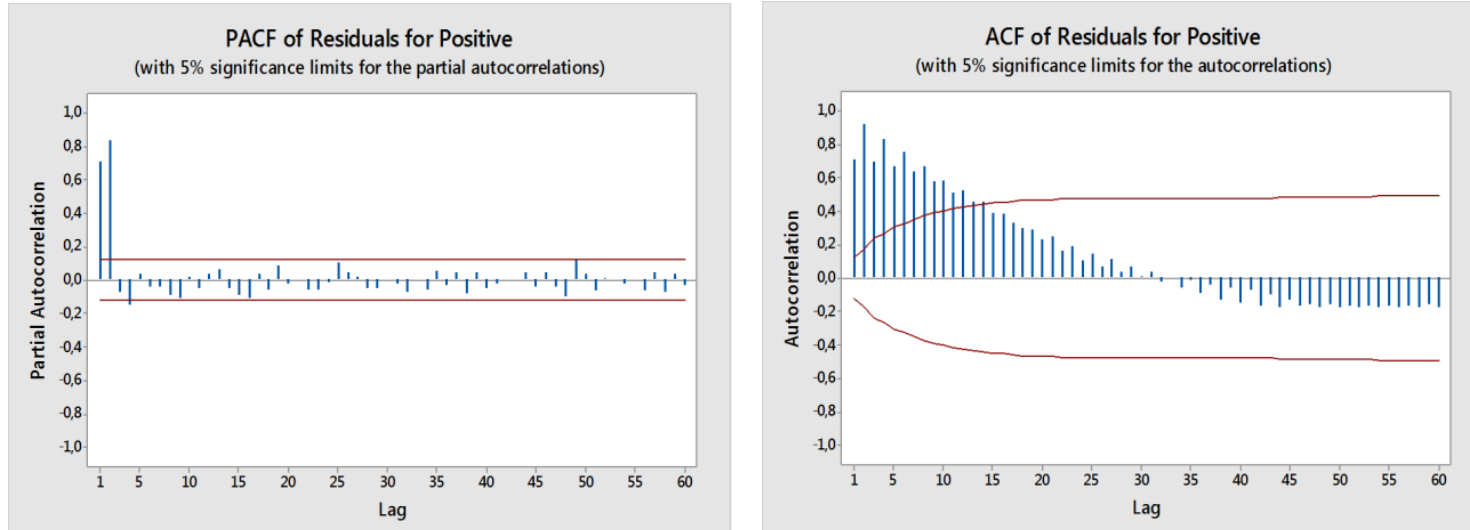

Figure 5. PACF and ACF of Residuals for COVID-19 for Positive Data (Data processed by Minitab 17)

In the time series model with the error probability $(\alpha) 5 \%$, the graph follows the ARIMA process $(0,1,1)$ with the p-Value MA $1(0.0 \%)$ is smaller than $\alpha$. The estimated results of parameters model for COVID-19 Positive Data using ARIMA model are shown in Table $\mathbf{1 .}$

Table 1. Final Estimates of Parameters Model for COVID-19 Positive Data

\begin{tabular}{ccccc}
\hline Type & Coef & SE Coef & T-Value & P-Value \\
\hline MA 1 & $-0,879$ & 0,033 & $-26,35$ & 0,000 \\
\hline Constant & 317,65 & 16,70 & 19,02 & 0,000 \\
\hline
\end{tabular}

Differencing: 1 regular difference. Number of observations: Original series 251, after differencing 250.

Referring to equation (4), mathematically the ARIMA model $(0,1,1)$ can be stated using coefficients in Table 1 as follows: $y_{t}=317.65-0.879 e_{t-1}$ 
medRxiv preprint doi: https://doi.org/10.1101/2020.12.18.20248340; this version posted December 20,

2020. The copyright holder for this preprint (which was not certified by peer review) is the

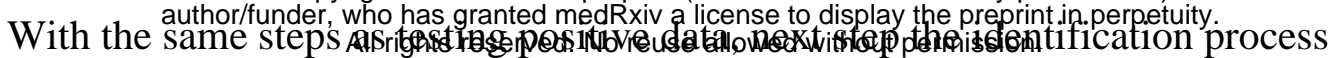

PACF and ACF from recovery data.

Same as COVID-19 positive data, Figure 6 to show PACF and ACF plots of

Residuals for COVID-19 Recovery data are obtained. The lag times through

PACF cuts off at lag one and ACF tails off slowly. In the time series model with

the error probability $(\alpha) 5 \%$, the graph follows the ARIMA process $(0,1,1)$ with

the P-Value MA $1(0,0 \%)$ is smaller than $\alpha$. The estimated of parameters for

COVID-19 Recovery data results using ARIMA model are reported in Table 2.
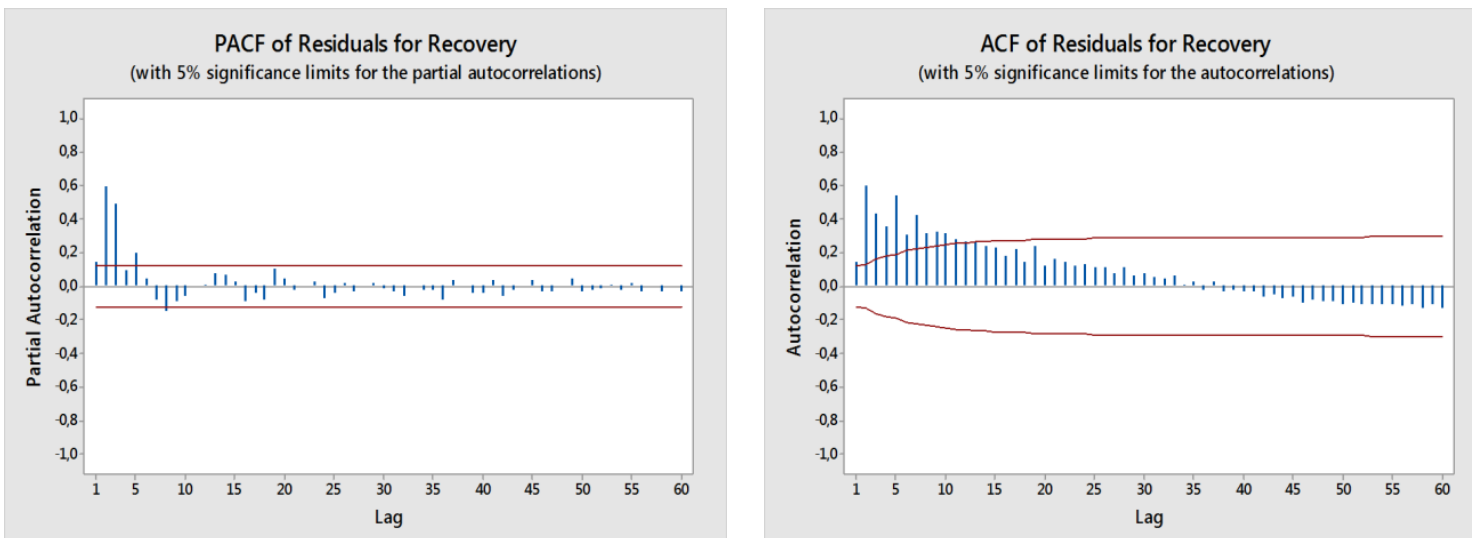

Figure 6. PACF and ACF of Residuals for COVID-19 Recovery Data (Data processed by Minitab 17)

Referring to equation (4), mathematically the ARIMA model $(0,1,1)$ in Table 2 can be stated as follows: $y_{t}=205.53-0.30 e_{t-1}$ 
medRxiv preprint doi: https://doi.org/10.1101/2020.12.18.20248340; this version posted December 20, 2020. The copyright holder for this preprint (which was not certified by peer review) is the

Table 2. Futhorffunder, who has granted medRxiv a license to display the reprint in perpetuity

\begin{tabular}{ccccc}
\hline Type & Coef & SE Coef & T-Value & P-Value \\
\hline MA 1 & $-0,30$ & 0,060 & $-4,93$ & 0,000 \\
\hline Constant & 205,53 & 13,14 & 15,64 & 0,000
\end{tabular}

Differencing: 1 regular difference, Number of observations: Original series 251, after differencing 250.

After positive and recovery data are analyzed, next the PACF and ACF models of the data death are shown in Figure 7. The PACF and ACF plots of residuals for COVID-19 death data are obtained. The lag time through PACF cuts off at lag two and ACF tails off slowly.
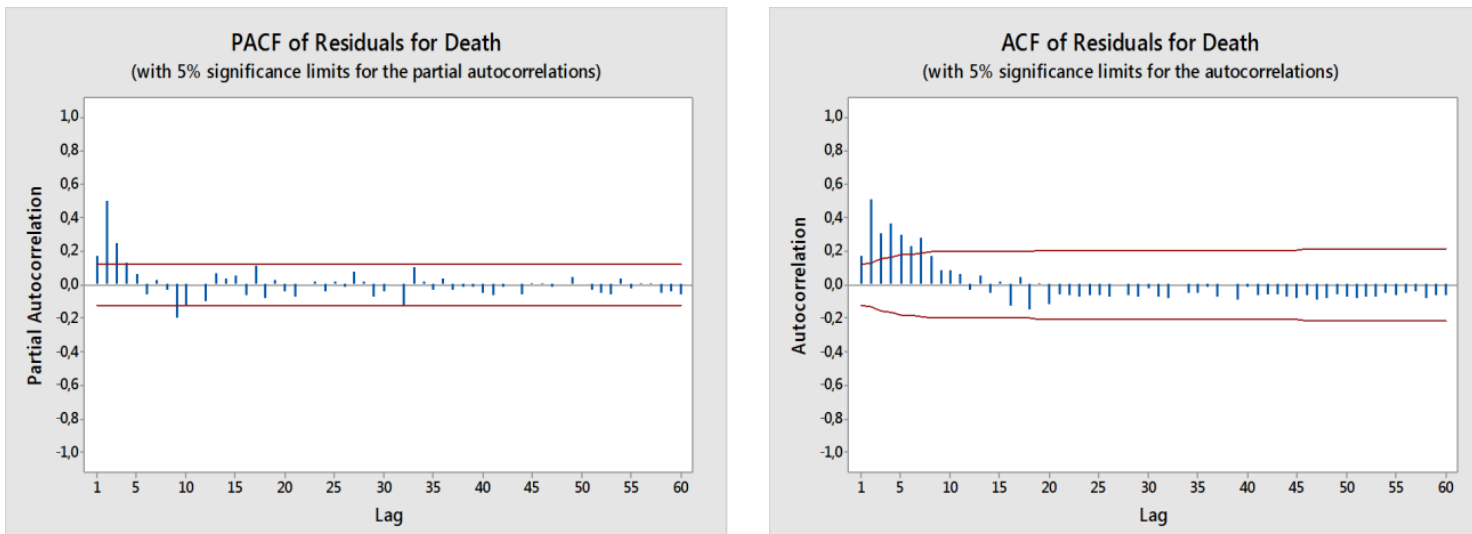

Figure 7. PACF and ACF of Residuals for COVID-19 Death Data (Data processed by Minitab 17)

In time series model with the error probability $(\alpha) 5 \%$, the graph follows the ARIMA process $(0,1,1)$ with the p-Value MA $1(0.00 \%)$ is smaller than $\alpha$. All estimated parameters results of the ARIMA model are shown in the Table 3. 
medRxiv preprint doi: https://doi.org/10.1101/2020.12.18.20248340; this version posted December 20,

2020. The copyright holder for this preprint (which was not certified by peer review) is the

Referring to equation, who has granted medRxiva a license to display the preprintin perpetuity.

using constant coefficient's obtained in Table 3 as follows: $y_{t}=9.343-0.415 e_{t-1}$

Table 3. Final Estimates of Parameters Model for COVID-19 Death Data

\begin{tabular}{ccccc}
\hline Type & Coef & SE Coef & T-Value & P-Value \\
\hline MA 1 & $-0,415$ & 0,056 & $-7,19$ & 0,000 \\
\hline Constant & 9,343 & 0,363 & 25,71 & 0,000
\end{tabular}

Differencing: 1 regular difference. Number of observations: Original series 251, after differencing 250.

Based on the results of predictions of COVID-19 cases that occurred in Algeria with a double exponential model and the results of PACF, ACF and estimated parameters model following the ARIMA model $(0,1,1)$ with the p-Value MA 1 is smaller than $\alpha$. The results of predictions of COVID-19 cases that occurred in Algeria (positive, recovery, and death) showed a gap in the resulting distribution patterns. Where the increase in the number of positive cases has not been offset by an increase in the number of patients who recovered and a decrease in the number of patients who died. This indicates that public behavior still does not comply with the rules set by the government (social distancing, large-scale social restrictions, mask use), the limited medical staff and the lack of standard equipment handling COVID-19 is one of the causes of the low handling of healing from positive patients. 
medRxiv preprint doi: https://doi.org/10.1101/2020.12.18.20248340; this version posted December 20, 2020. The copyright holder for this preprint (which was not certified by peer review) is the

4. Disthorfunder who has granted medRxiv a license to display the preprint in perpetuity.

4. DISCUSSIOAN rights reserved. No reuse allowed without permission.

Since the WHO declared COVID-19 a pandemic in March $11^{\text {th }}, 2020$, several countries including Algeria experienced an exponential rise in COVID-19 cases [7]. This rapid increase of cases has stressed most healthcare systems worldwide and has further made outbreak response and resource planning a challenge. In response, health authorities have attempted to forecast the trend of this pandemic, however this have proven to be difficult as COVID-19 is a novel disease with limited data and knowledge on the disease trends and dynamics [6]. This is especially observed when using ARIMA model to predict disease trends, where ARIMA model require sufficient long time series data to be accurate.

Our forecast also showed an accurate trend which corresponded to the positive cases observed and reported by the ministry of health in Algeria during three days $(252,253$ and 254). The same situation has been obtained for forecasted recovery and death cases.

As shown in Table 4, this finding is strengthened by variations of less than 5\% between the forecast and observed cases in $100 \%$ of the forecasted data points. This paper demonstrates that ARIMA models are a suitable tool to forecast case trends especially during situations where data is limited. 
medRxiv preprint doi: https://doi.org/10.1101/2020.12.18.20248340; this version posted December 20, 2020. The copyright holder for this preprint (which was not certified by peer review) is the

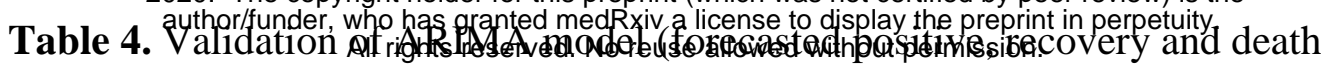
cases) with $5 \%$ significance limits

\begin{tabular}{l|cccc|cccc|cccc} 
& \multicolumn{4}{|c|}{ Forecasts positive cases } & \multicolumn{4}{c|}{ Forecasts recovery cases } & \multicolumn{4}{c}{ Forecasts death cases } \\
\hline $\begin{array}{l}\text { Days } \\
\text { forecasted }\end{array}$ & Forecast & Lower & Upper & Actual & Forecast & Lower & Upper & Actual & Forecast & Lower & Upper & Actual \\
\hline 252 & 80172.9 & 80118.1 & 80227.7 & $\mathbf{8 0 1 6 8}$ & 51958.5 & 51825.1 & 52092.0 & $\mathbf{5 1 9 4 6}$ & 2372.04 & 2366.75 & 2377.33 & $\mathbf{2 3 7 2}$ \\
\hline 253 & 81240.6 & 81129.2 & 81352.0 & $\mathbf{8 1 2 2 1}$ & 52579.8 & 52414.9 & 52744.7 & $\mathbf{5 2 5 6 8}$ & 2392.53 & 2384.94 & 2400.11 & $\mathbf{2 3 9 3}$ \\
\hline 254 & 82308.3 & 82139.5 & 82477.2 & $\mathbf{8 2 2 2 1}$ & 53201.1 & 53001.9 & 53400.3 & $\mathbf{5 3 2 0 4}$ & 2413.02 & 2402.99 & 2423.04 & $\mathbf{2 4 1 0}$ \\
\hline
\end{tabular}

Bold values are the reel values reported by the ministry of health and hospital reform of Algeria.

Similarly, studies on COVID-19 conducted in countries such as South Korea, Iran and Italy were able to predict case trends using ARIMA models in similar conditions. In addition as with our findings, a study in Italy also reported a high level of forecast accuracy of 95\% in predicting COVID-19 trends using ARIMA models [14-19-20].

The strengths of this study include, firstly, this paper is the first to report the use of ARIMA models to forecast COVID-19 cases and trends in Algeria. Secondly, this was the first attempt to use smoothen case data to improve accuracy as compared to similar studies on ARIMA models for COVID-19 conducted in other countries [20-21]. Thirdly, we used several independent covariates which provided more accurate signals to develop short-term model predictions for immediate outbreak response. And finally, we also optimized the model training and validation period to provide the highest number of data points to generate the best fit model. 
medRxiv preprint doi: https://doi.org/10.1101/2020.12.18.20248340; this version posted December 20, 2020. The copyright holder for this preprint (which was not certified by peer review) is the

5. COuthor/funder wh has granted medRxiv a license to display the preprint in perpetuity.

5. CONCLUSIA) Ayhts reserved. No reuse allowed without permission.

This study demonstrated the effectiveness of ARIMA models as an early warning strategy that can provide accurate COVID-19 forecasts on larger data points (251 days). ARIMA models are not only effective but it's a simple and easy tool by which COVID-19 trends can be predicted based on open access data. The forecasted values of positives, recovery and death cases of COVID-19 shown an accurate trend which corresponded to the actual cases observed and reported by the ministry of health in Algeria during three days (252, 253 and 254). In addition, the use of smoothened data and independent covariates improved the model accuracy. We are confident that the ARIMA model can be used to generate accurate and reliable forecasts of daily COVID-19 cases until the end of COVID19 with the addition of new data points and independent covariates.

Declaration of competing interest: I have no known competing financial interests or personal relationships that could have appeared to influence the work reported in this paper.

Acknowledgement: The authors would like to thank the Ministry of Health, Population and Hospital Reform of Algeria. We also thank the John Hopkins University for publicly releasing the updated datasets on the number of infected cases of COVID-19. 
medRxiv preprint doi: https://doi.org/10.1101/2020.12.18.20248340; this version posted December 20, 2020. The copyright holder for this preprint (which was not certified by peer review) is the REFERENCES All rights reserved. No reuse allowed without permission.

[1] Gan WH, Lim JW, David KO. Preventing intra-hospital infection and transmission of COVID-19 in healthcare workers. Saf Health Work 2020; 11: 241-243.

[2] Xu X-W, Wu X-X, Jiang X-G, Xu K-J, Ying L-J, Ma C-L, Li S-B, Wang HY, Zhang S, Gao H-N, Sheng J-F, Cai H-L, Qiu Y-Q, Li L-J. Clinical findings in a group of patients infected with the 2019 novel coronavirus (SARS-Cov-2) outside of Wuhan, China: retrospective case series. BMJ 2020; 368.

[3] World Health Organization. Coronavirus disease (COVID-19) outbreak situation URL: https://www.who.int/emergencies/ diseases/novel-coronavirus2019 [Accessed: November 26, 2020].

[4] Kuniya T. Prediction of the epidemic peak of coronavirus disease in Japan. J Clin Med 2020; 9:783

[5] Linton NM, Kobayashi T, Yang Y, Hayashi K, Akhmetzhanov AR, Jung S, et al. Incubation period and other epidemiological characteristics of 2019 novel coronavirus infections with right truncation: a statistical analysis of publicly available case data. J Clin Med 2020; 9: 538. 
medRxiv preprint doi: https://doi.org/10.1101/2020.12.18.20248340; this version posted December 20,

2020. The copyright holder for this preprint (which was not certified by peer review) is the

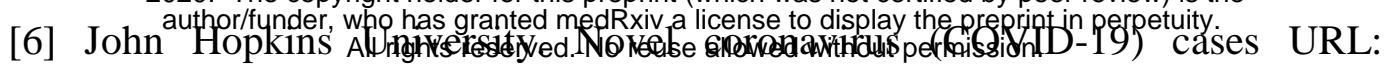

https://coronavirus.jhu.edu/region/algeria [Accessed: November 26, 2020].

[7] Wang C, Horby Pw, Hayden Fg and Gao Gf. A novel coronavirus outbreak of global health concern. Lancet 2020, 395, 470-3.

[8] Kucharski AJ, Russell TW, Diamond C, Liu Y, Edmunds J, Funk S, Eggo

RM, Sun F, Jit M, Munday JD, Davies N, Gimma A, van Zandvoort K, Gibbs H,

Hellewell J, Jarvis CI, Clifford S, Quilty BJ, Bosse NI, Abbott S, Klepac P,

Flasche S: Early dynamics of transmission and control of COVID-19: a mathematical modelling study. Lancet Infect. Dis 2020; 20: 553-558.

[9] Pirouz B, Shaffiee Haghshenas S, Shaffiee Haghshenas S, Piro P. Investigating a serious challenge in the sustainable development process: analysis of confirmed cases of COVID-19 (new type of coronavirus) through a binary classification using artificial intelligence and regression analysis. Sustain 2020;12:2427.

[10] Allard R. Use of time-series analysis in infectious disease surveillance. Bull World Health Organ 1998; 76: 327-333. 
medRxiv preprint doi: https://doi.org/10.1101/2020.12.18.20248340; this version posted December 20,

2020. The copyright holder for this preprint (which was not certified by peer review) is the

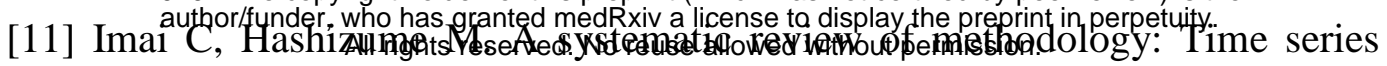

regression analysis for environmental factors and infectious diseases. Trop Med

Health 2015; 43: 1-9.

[12] Benvenuto D, Giovanetti M, Vassallo L, Angeletti S, Ciccozzi M.

Application of the ARIMA model on the COVID-2019 epidemic dataset. Data in

Brief 2020; 29: 1-4.

[13] Chintalapudi N, Battineni G, Amenta F. COVID-19 virus outbreak forecasting of registered and recovered cases after sixty day lockdown in Italy: A data driven model approach. J Microbiol Immunol Infect 2020; 53: 396-403.

[14] Singh S, Sundram BM, Rajendran K, Law KB, Aris T, Ibrahim H, Dass SC,

Gill BS. Forecasting daily confirmed COVID-19 cases in Malaysia using ARIMA models. J Infect Dev Ctries 2020;14.

[15] Singh RK, Rani M, Bhagavathula AS, Sah R, Rodriguez-Morales AJ, Kalita H, Nanda C, Sharma S, Sharma YD, Rabaan AA, Rahmani J, Kumar P. Prediction of the COVID-19 Pandemic for the Top 15 Affected Countries: Advanced Autoregressive Integrated Moving Average (ARIMA) Model. JMIR Public Health Surveill 2020 ; 6. 
medRxiv preprint doi: https://doi.org/10.1101/2020.12.18.20248340; this version posted December 20,

2020. The copyright holder for this preprint (which was not certified by peer review) is the

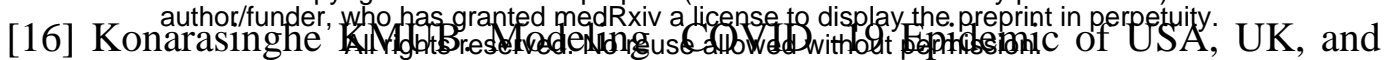

Russia. JNFHBS 2020; 1: 1-14.

[17] Cheung YW, La KS. Lag order and critical values of the augmented dickey-

fuller test. J Bus Econ Stat 1995; 13: 277-280.

[18] Harini S. Identification COVID-19 Cases in Indonesia with The Double

Exponential Smoothing Method. J Mat Mantik 2020; 6: 66-75.

[19] Dehesh T, Mardani-Fard HA, Dehesh P. Forecasting of COVID-19

Confirmed Cases in Different Countries with ARIMA Models. medRxiv 2020.

Preprints.

[20] Chintalapudi N, Battineni G, Amenta F. COVID-19 virus outbreak forecasting of registered and recovered cases after sixty day lockdown in Italy: A data driven model approach. J Microbiol Immunol Infect 2020; 53: 396-403.

[21] Benvenuto D, Giovanetti M, Vassallo L, Angeletti S, Ciccozzi M. Application of the ARIMA model on the COVID-2019 epidemic dataset. Data in Brief 2020; 29: 1-4. 